\title{
HAK EKONOMI DAN HAK MORAL KARYA CIPTA POTRET DI SOSIAL MEDIA
}

\author{
Oleh \\ Desyanti Suka Asih K.Tus \\ Fakultas Dharma Duta
}

\begin{abstract}
Copyright is an exclusive right which contains economic rights and moral rights. Portrait is part of a protected creation. In a portrait that is distributed offline or online through social media, namely economic rights and moral rights that must be presented and adhered to by users. Copyright infragement that still occur for portraits on social media are related to violations of economic and moral rights. The use of portraits on social media without permission for commercial purposes is a form of violation of economic rights. While the form of violations of moral rights over portraits is not to include the creator or source of portraits used in social media. The regulation and protection of economic and moral rights of portraits on social media are regulated in the Copyright Law. Economic rights are stipulated in Article 12 to Article 15. Moral rights are stipulated in Article 5 to Article 7.
\end{abstract}

\section{PEDAHULUAN}

Persoalan mengenai pelanggaran Hak Kekayaan Intelektual (selanjutnya disingkat HKI) hingga saat ini masih menjadi momok bagi bangsa ini. Pelanggaran-pelanggaran terhadap HKI masih banyak terjadi bahkan semakin marak. Pada kenyataanya HKI merupakan sesuatu yang harus mendapat perlindungan karena HKI berkaitan erat dengan aspek teknologi, aspek ekonomi, maupun seni budaya dari suatu bangsa. Dimana setiap hal yang dilahirkan melalui daya cipta, rasa dan karsa manusia perlu mendapat perlindungan hukum, karena karya manusia ini telah dihasilkan melalui suatu daya intelektualiatas yang memerlukan pengorbanan tenaga, pikiran, waktu, bahkan biaya yang tidak sedikit. Untuk memperoleh suatu karya yang asli dalam konteks HKI memerlukan biaya yang sangat besar. Oleh karena itu modal merupakan unsur yang sangat penting sehingga para pemilik modal merasa bahwa kepentingannya harus dilindungi.
Menurut WIPO (World Intellectual Porperty Organisation) HKI digolongkan menjadi dua:

1. Hak Cipta (Copyrights)

2. Hak Kekayaan Industri (industrial property rights)

Yang termasuk dalam Hak Kekayaan Industri antara lain Hak Paten, Merek, Hak Desain Industri, Desain Tata Letak Sirkuit Terpadu, Rahasia Dagang, dan Varietas Tanaman. Dalam tulisan ini yang akan dibahas adalah berkaitan dengan Hak Cipta

Melihat sejarah peraturan-perundangundangan tentang Hak Cipta di Indonesia, diawali dari pemberlakuan Auteurswet 1912 dengan Staatsblad 1912 No.600 yang berlaku di Indonesai berdasarkan ketentuan Pasal II Aturan Peralihan UUD 1945. Auteurswet 1912 dianggap sebagai UU yang mati karena tidak memberikan perlindungan pada Hak Cipta, UU tentang Hak Cipta kemudian mengalami beberapa kali 
perubahan. Di mulai dengan diberlakukannya Undang-undang Nomor 6 Tahun 1982 (UUHC 1982). UUHC 1982 juga tidak dapat memberikan perlindungan yang memadai bagi Hak Cipta sehingga perlu di lakukan perubahan dengan Undang-Undang Nomor 7 Tahun 1987 (UUHC 1987). UUHC 1987 kemudian di perbaharui dengan pemberlakukan Undang-undang Nomor 12 Tahun 1997 (UUHC). UUHC 1997 kemudian dirubah dengan pemberlakuan Undang-undang Nomor 19 Tahun 2002 (UUHC 2002). UUHC 2002 kemudian dilakukan perubahan dengan memberlakukan Undang-Undang Nomor 28 Tahun 2014 (UUHC). Pembentukan undangundang ini dalam upaya bagi pemberian perlindungan bagi pemegang Hak Cipta.

Sejarah panjang peraturan perundangundangan Hak Cipta di Indonesia ternyata tidak secara signifikan menjadikan Indonesia sebagai negara dengan perlindungan Hak Cipta yang memadai khususnya Hak Cipta atas potret di sosial media. Indonesia bahkan pernah dimasukkan dalam katagori Priority Watch List (daftar negara yang menjadi prioritas untuk diawasi) untuk kasus pelanggaran HKI. Bahkan setelah kehadiran UUHC pelanggaran terhadap Hak Cipta masih terjadi.

Kasus yang menimpa selebriti dan presenter, Farah Quinn, menggugat sebuah situs belanja online karena menggunakan foto dirinya tanpa persetujuan untuk kepentingan komersial. Farah, yang didampingi tim kuasa hukumnya saat jumpa pers menceritakan, kasus tersebut berawal dari seorang teman yang menghubunginya dan mengonfirmasi tentang keberadaan fotonya di situs belanja. Setelah diperiksa, Quinn menyadari bahwa ia tidak pernah memberikan persetujuan kepada online shop tersebut. Foto pertama yang dipajang merupakan foto untuk produk pisau milik Beattix Shop. Padahal, foto tersebut sebenarnya digunakan untuk cover Buku Health Happy Family by Farah Quinn. Kemudian, foto lainnya yang juga dipajang adalah foto untuk produk double fry pan milik Modern House, di mana foto itu pernah digunakan Farah untuk produk iklan Tupperware. Tim kuasa hukum Farah telah mengajukan laporan dugaan tindak pidana terkait penggunaan foto-foto tersebut untuk kepentingan iklan komersial di media e-commerce berdasarkan UU No.1 Tahun 2008 tentang Informasi dan Transaksi Elektronik ke Mabes Polri. Selain itu, akan diupayakan gugatan terkait pelanggaran hak cipta di Pengadilan Niaga pada Pengadilan Negeri Jakarta Pusat. $^{1}$

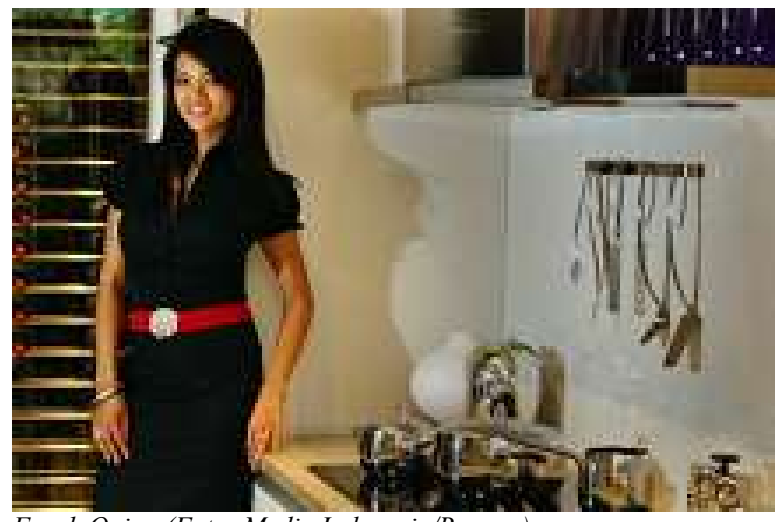

Farah Quinn (Foto: Media Indonesia/Rommy) http://hiburan.metrotvnews.com/selebritas/ZkenGOqK-fotonyadipakai-tanpa-izin-farah-quinn-gugat-online-shop

Kasus penggunaan potret pada pembuatan sebuah video klip musik, yaitu video klip "Akad" Payung Teduh. Produser video klip tersebut membuat alur kisah yang bercerita mengenai seorang Bapak yang terlebih dahulu ditinggalkan istrinya karena meninggal dunia. Sosok almarhum ibu dalam video klip tersebut digambarkan melalui sebuah potret foto. Potret sosok ibu yang digunakan dalam video klip tersebut diketahui bernama Kairo yang merupakan warga negara Jepang. Potret diri ibu Kairo itu ternyata digunakan tanpa ijin dan tanpa sepengetahuan dari ibu Kairo. ${ }^{1}$

Kasus lain yang terjadi di tahun 2018 adalah yang menimpa Maulina Pia Wulandari yang adalah Dosen Ilmu Komunikasi FISIP Universitas Brawijaya, Malang. Potretnya diunggah seorang public figure tanah air Denny Cagur secara tanpa izin dan diedit di akun Instagram. ${ }^{2}$ 


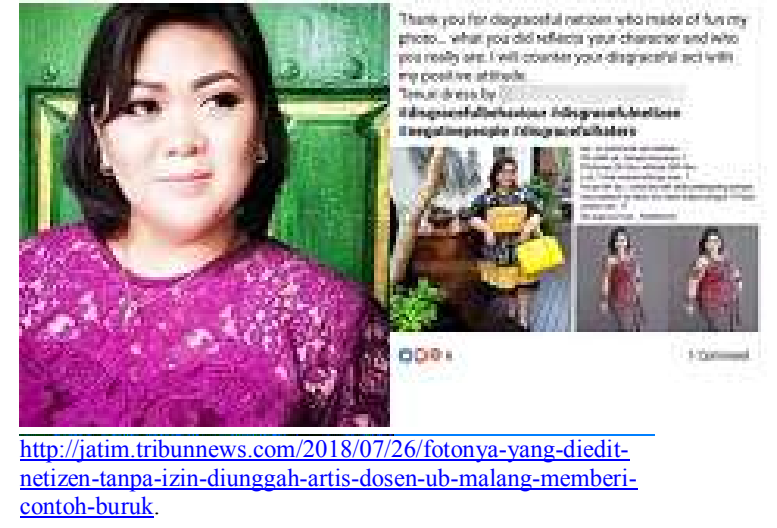

Ketiga contoh kasus diatas menunjukkan bahwa penggunaan potret tanpa izin yang mengakitbatkan terjadinya pelanggaran Hak Cipta masih terjadi di Indonesia. Menggunakan potret tanpa izin khususnya di sosial media terkait dengan pelanggaran atas Hak Ekonomi dan Hak Moral dari pencipta termasuk orang yang dipotret.

Kehadiran internet sebagai era baru di dunia memberikan berbagai kemudahan bagi manusia. Negara bukan lagi halangan untuk bertukar informasi. Komunikasi dapat dilakukan dengan mudah sekalipun berada di benua yang berbeda. Kehadiran sosial media juga menjamur. Sosial media kemudian menjadi wadah bertukar informasi tanpa mengenal batas-batas negara. Satu kali klik, informasi dapat beredar dengan mudah.

Social media is, in relative terms, a recent phenom- enon. Whether enjoyed or shunned, it is true that millions of people use various platforms for a whole number of reasons:

- news;

- politics;

- connection with friends;

- business;

- writing;

- idea generation; or

- simply for fear of missing out. ${ }^{1}$

Tanpa disadari, segala kemudahan yang didapat dengan kehadiran internet dan sosial media telah menjadi media pelanggaran khususnya Hak Cipta atas potret. Perkembangan teknologi memungkinkan seseorang melakukan pengambilan potret secara online tanpa izin kemudian mempublikasikannya lagi bahkan melakukan editting terlebih dahulu. Hal ini menunjukan bahwa tidak hanya memberi kemudahan pada manusia, kehadiran internet dan sosial media dapat membawa dampak negatif ketika dipergunakan tanpa pengetahuan dan tanggung jawab.

Sebagai hak ekslusif (exclusive rights), Hak Cipta mengandung dua esensi hak, yaitu: hak ekonomi (economic rights) dan hak moral (moral rights). Kandungan hak ekonomi meliputi hak untuk mengumumkan (performing rights) dan hak memperbanyak (mechanical rights). Ada pun hak moral meliputi hak pencipta untuk dicantumkan namanya dalam ciptaannya, termasuk judul atau pun anak judul ciptaan. ${ }^{2}$ Hak inilah yang kemudian dilanggar dan menimbulkan pelanggaran Hak Cipta atas potret khususnya di sosial media.

\section{RUMUSAN MASALAH}

Rumusan masalah dalam tulisan ini adalah bagaimanakah pengaturan perlindungan Hak Ekonomi dan Hak Moral atas potret di sosial media?

\section{TEORI}

John Locke mengemukakan bahwa hak atas property lahir dan ada karena adanya usaha dan pengorbanan waktu dan tenaga yang telah diberikan dan diinvestasikan untuk menghasilkan property tersebut. Oleh karena itu lahirlah hak yang melekat pada karya intelektual sebagai hasil investasi kreatif seseorang (Creative people have an inherent right to their intellectual property because of the labour they have invested in it). ${ }^{3}$

\section{METODE}

Tulisan ini merupakan penelitian hukum normatif yang dimaksudkan untuk mendapatkan jawaban terhadap permasalahan Hak Ekonomi dan Hak Moral Karya Cipta Potret di Sosial Media. Pendekatan yang dipergunakan dalam penelitian ini adalah pendekatan perundangundangan. Karena itu, peraturan perundangundangan dijadikan sebagai obyek kajian dalam penelitian ini. Disamping itu, dalam tulisan ini digunakan juga pendekatan konseptual. Dalam 
penelitian hukum terdapat dua jenis sumber bahan hukum yaitu bahan hukum primer dan bahan hukum sekunder. ${ }^{4}$ Teknik pengumpulan bahan hukum yang dipergunakan adalah studi kepustakaan/studi dokumen.

\section{PEMBAHASAN}

\subsection{Pengaturan Perlindungan Hak Ekonomi Potret di Sosial Media}

Hak ekonomi adalah hak untuk mendapatkan manfaat ekonomi dari suatu ciptaan dan produk terkait. Sementara hak moral adalah hak yang melekat pada pencipta yang tidak dapat dihilangkan atau dihapuskan walaupun hak cipta telah dialihkan. Dengan demikian jelas bahwa hak ekonomi dapat dialihkan kepada pihak lain oleh pencipta sementara hak moral tetap melekat pada diri pencipta walaupun hak ekonominya telah beralih. Dengan hak ekonomi, pencipta dapat mengeksploitasi ciptaanya guna mendapatkan manfaat ekonomi, sementara hak moral adalah manunggal dengan penciptanya. Seseorang tidak dapat mengubah, atau mengganti judul, isi apalagi penciptanya. Hal ini hanya dapat dilakukan dengan izin dari pencipta atau ahli warisnya jika pencipta telah meninggal dunia. ${ }^{5}$

Kandungan hak ekonomi meliputi hak untuk mengumumkan (performing rights) dan hak memperbanyak (mechanical rights). Ada pun hak moral meliputi hak pencipta untuk dicantumkan namanya dalam ciptaannya, termasuk judul atau pun anak judul ciptaan. 6

Pengaturan hak ekonomi dari potret diatur dalam Pasal 12 sampai Pasal 15 UUHC

Pasal 12

(1) Setiap Orang dilarang melakukan Penggunaan Secara Komersial, Penggandaan, Pengumuman, Pendistribusian, dan/ atau Komunikasi atas Potret yang dibuatnya guna kepentingan reklame atau periklanan secara komersial tanpa persetujuan tertulis dari orang yang dipotret atau ahli warisnya.

(2) Penggunaan Secara Komersial, Penggandaan, Pengumuman, Pendistribusian, dan/ atau Komunikasi Potret sebagaimana dimaksud pada ayat (1) yang memuat Potret 2 (dua) orang atau lebih, wajib meminta persetujuan dari orang yang ada dalam Potret atau ahli warisnya

\section{Pasal 13}

Pengumuman, Pendistribusian, atau Komunikasi Potret seorang atau beberapa orang Pelaku Pertunjukan dalam suatu pertunjukan umum tidak dianggap sebagai pelanggaran Hak Cipta, kecuali dinyatakan lain atau diberi persetujuan oleh Pelaku Pertunjukan atau pemegang hak atas pertunjukan tersebut sebelum atau pada saat pertunjukan berlangsung.

\section{Pasal 14}

Untuk kepentingan keamanan, kepentingan umum, dan/atau keperluan proses peradilan pidana, instansi yang berwenang dapat melakukan Pengumuman, Pendistribusian, atau Komunikasi Potret tanpa harus mendapatkan persetujuan dari seorang atau beberapa orang yang ada dalam Potret.

\section{Pasal 15}

(1) Kecuali diperjanjikan lain, pemilik dan/atau pemegang Ciptaan fotografi, lukisan, gambar, karya arsitektur, patung, atau karya seni lain berhak melakukan Pengumuman Ciptaan dalam suatu pameran umum atau Penggandaan dalam suatu katalog yang diproduksi untuk keperluan pameran tanpa persetujuan Pencipta.

(2) Ketentuan Pengumuman Ciptaan sebagaimana dimaksud pada ayat (1) berlaku juga terhadap Potret sepanjang tidak bertentangan dengan ketentuan sebagaimana dimaksud dalam Pasal 12.

Ketentuan yang diatur dalam Pasal 12 sampai Pasal 15 UUHC, kurang lebih sama dengan ketentuan Pasal 19 sampai Pasal 23 UUHC 2002. Dimana ketetuan-ketentuan tersebut lebih kepada pembatasan potret sebagai ciptaan yang dilindungi. Sehingga dirasa kurang tepat disebut sebagai Hak Ekonomi Atas Potret. ${ }^{7}$ Alasan kurang tepatnya penyebutan ketentuan tersebut disebut Hak Ekonomi Atas Potret adalah: 1. Substansi Pasal 12 sampai Pasal 15 UUHC ini merupakan ketentuan yang membatasi Hak 
Cipta atas potret, sama seperti ketentuan Pasal 19 sampai Pasal 23 UUHC 2002.

2. Isi ketentuan Pasal 12 sampai Pasal 15 UUHC menunjukkan bahwa pencipta atau pemegang Hak Cipta atas ciptaan potret adalah orang yang dipotret, padahal tidak demikian. Karena apabila yang dianggap sebagai pencipta atau pemegang Hak Cipta atas potret adalah orang yang dipotret, hal ini bertentangan dengan ketentuan Pasal 1 angka 3 tentang ciptaan. Dimana ciptaan adalah hasil karya cipta dibidang ilmu pengetahuan, seni, dan sastra yang dihasilkan atas inspirasi, kemampuan, pikiran, imajinasi, kecekatan, keterampilan, atau keahlian yang diekspresikan dalam bentuk nyata. Unsur-unsur tersebut tidak ada pada diri orang yang dipotret. Sehingga yang lebih tepat dianggap sebagai pencipta atau pemegang Hak Cipta atas potret adalah pembuat potret (pemotret). ${ }^{8}$

Ketentuan yang tertuang dalam Pasal 12 sampai Pasal 15 UUHC sekalipun dikritik dan dirasa lebih tepat berjudul pembatasan Hak Cipta atas potret, tetapi didalamnya memuat pengaturan perlindugan hak ekonomi atas potret.

Dihubungkan dengan kasus-kasus pelanggaran Hak Cipta atas potret yang terjadi di sosial media dan menimpa mulai dari kalangan selebriti, akademisi hingga warga negara asing, ketentuan Pasal 12 UUHC telah secara jelas menyatakan bahwa setiap orang dilarang menggunakan potret untuk segala bentuk tujuan komersial tanpa izin dari orang yang dipotret atau ahli warisnya. Penggunaan atas potret di segala bentuk media baik offline maupun online harus tunduk pada ketantuan Pasal 12 sampai Pasal 15 UUHC, karena esensi dari ketentaun yang tertuang adalah mengenai perlindungan Hak Ekonomi atas potret yang dituangkan dalam bentuk pembatasanpembatasan dalam menggunakan potret secara komersial.

Farah Quinn dan Ibu Kaori yang potretnya dipergunakan untuk kepentingan komersial di salah satu online shop dan produksi video klip salah satu band Indonesia tanpa izin, jelas telah melanggar hak ekonomi dari pencipta potret sekaligus dari orang yang dipotret. Tindakan ini telah merugikan secara ekonomi bagi pencipta potret. Atas tindakan tersebut UUHC Pasal 115 mengatur "Setiap Orang yang tanpa persetujuan dari orang yang dipotret atau ahli warisnya melakukan Penggunaan Secara Komersial, Penggandaan, Pengumuman, Pendistribusian, atau Komunikasi atas Potret sebagaimana dimaksud dalam Pasal 12 untuk kepentingan reklame atau periklanan untuk Penggunaan Secara Komersial baik dalam media elektonik maupun non elektronik, dipidana dengan pidana denda paling banyak Rp500.000.000,00 (lima ratus juta rupiah)."

Ketentuan Pasal 115 UUHC ini menunjukkan adanya upaya perlindungan penggunaan potret di sosial media yang tidak hanya terbatas pada pengajuan gugatan ke Pengadilan Niaga tetapi dapat menempuh upaya tuntutan pidana.

Pengaturan perlindugnan hak ekonomi dari pencipta potret yang tertuang dalam ketentuan Pasal 12 sampai 15 UUHC, Pasal 40 ayat (1), hingga ketentuan pemidanaan yang tertuang dalam ketentuan Pasal 115 UUHC sejalan dengan teori John Locke yang mengemukakan bahwa hak atas property lahir dan ada karena adanya usaha dan pengorbanan waktu dan tenaga yang telah diberikan dan diinvestasikan untuk menghasilkan property tersebut. Oleh karena itu lahirlah hak yang melekat pada karya intelektual sebagai hasil investasi kreatif seseorang (Creative people have an inherent right to their intellectual property because of the labour they have invested in it). ${ }^{9}$

Perlindungan yang di berikan oleh UUHC melalui ketentuan-ketentuan dalam pasal-pasalnya, walaupun masih terdapat kelemahan, merupakan salah satu upaya pemerintah memberikan kepastian hukum, penghargaan kepada pencipta atas kerja kerasnya melahirkan sebuah karya cipta dalam hal ini adalah potret. Potret adalah potperty. Di dalam konsep potperty ada unsur kepemilikan, dimana potret yang dihasilkan pasti ada pemiliknya. Dalam hal ini adalah pencipta atau pemegang Hak Cipta atas potret. Sehingga setiap penggunaan potret dimanapun, offline maupun online terlebih untuk 
kepentingan komersial harus mendapatkan izin terlebih dahulu dari orang yang di potret, pencipta, atau pemegang Hak Cipta atas potret. Kecuali atas keperluan komersial tersebut telah diperjanjikan lain oleh para pihak.

\subsection{Pengaturan Perlindungan Hak Moral Potret di Sosial Media}

Secara doktrinal, hak moral terdiri dari hak-hak yang sebagai berikut:

a. Hak pengakuan sebagai pencipta (paternity right atau authorship right) apabila karya cipta yang dihasilkan oleh pencipta tersebut diperbanyak, diumumkan atau dipamerkan dihadapan publik. Karya tersebut harus mencantumkan nama penciptanya.

b. Hak keutuhan karya (the right to protect the integrity of the work) yakni hak yang dimiliki untuk tidak merubah karya cipta tanpa adanya persetujuan dari pencipta, atau ahli waris dari pencipta itu sendiri. Perubahan tersebut misalnya dilakukan dengan pemutarbalikan, perusakan, pemotongan, dan penggantian yang berhubungan dengan karya cipta.

c. Hak pencipta untuk menggandakan hasil perubahan pada karya cipta sesuai dengan dinamika perkembangan zaman serta kepatutan yang berlaku di dalam kehidupan masyarakat. ${ }^{10}$

Uraian diatas menunjukkan bahwa hak moral melekat pada pencipta. Sekalipun ciptaan telah digandakan dan dirubah sebagaian kecil maupun sebagaian besar, hak moral tetap harus dipenuhi sebagai bentuk pengakuan terhadap pencipta.

Pengaturan hak moral dalam UUHC terdapat pada Pasal 5 sampai Pasal 7.

Pasal 5

(1) Hak moral sebagaimana dimaksud dalam Pasal 4 merupakan hak yang melekat secara abadi pada diri Pencipta untuk:

a. tetap mencantumkan atau tidak mencantumkan namanya pada salinan sehubungan dengan pemakaian Ciptaannya untuk umum; b. menggunakan nama aliasnya atau samarannya;

c. mengubah Ciptaannya sesuai dengan kepatutan dalam masyarakat;

d. mengubah judul dan anak judul Ciptaan; dan

e. mempertahankan haknya dalam hal terjadi distorsi Ciptaan, mutilasi Ciptaan, modifikasi Ciptaan, atau hal yang bersifat merugikan kehormatan diri atau reputasinya.

(2) Hak moral sebagaimana dimaksud pada ayat (1) tidak dapat dialihkan selama Pencipta masih hidup, tetapi pelaksanaan hak tersebut dapat dialihkan dengan wasiat atau sebab lain sesuai dengan ketentuan peraturan perundangundangan setelah Pencipta meninggal dunia.

(3) Dalam hal terjadi pengalihan pelaksanaan hak moral sebagaimana dimaksud pada ayat (2), penerima dapat melepaskan atau menolak pelaksanaan haknya dengan syarat pelepasan atau penolakan pelaksanaan hak tersebut dinyatakan secara tertulis.

Pengaturan ini berlaku bagi seluruh ciptaan yang dilindungi.

Jika kasus yang menimpa selebritis dan presenter Farah Quinn lebih menonjol pada pelanggaran hak ekonomi, karena potret dirinya dipergunakan untuk kepentingan komersial, bebeda dengan kasus yang menimpa Maulina Pia Wulandari. Potret dirinya di edit kemudian diunggah oleh public figure Denny Cagur tanpa izin di Instagram. Tindakan ini memang tidak dilakukan demi keuntungan komersial, tidak ada keuntungan ekonomi yang diperoleh dari tindakan ini. Tetapi tindakan ini merupakan pelanggaran hak moral dari pencipta atau pemegang Hak Cipta atas potret. Tindakan ini juga melanggar hak moral dari orang yang potret karena dengan melakukan editing telah mengakibatkan perubahan yang mana tidak sesuai dengan keadaan yang sesuai pada saat potret tersebut diambil dan tanpa izin orang yang di potret.

Tindakan yang dilakukan oleh Denny Cagur melanggar ketentuan Pasal 5 UUHC. Karena tidakan itu telah mendistorsi hak moral dari 
pencipta, pemegang Hak Cipta serta orang yang di potret. Penggunaan potret tanpa izin telah mengesampingkan pengakuan atas diri pencipta yang melekat pada diri pencipta. Sifat dari hak moral yang melekat dengan penciptanya, mengharuskan dimanapun ciptaan dipergunakan dan oelh siapapun, sudah menjadi kewajiban dari pengguna untuk selalu mencantumkan nama pencipta atau sumber ciptaan tersebut diambil.

Lebih lanjut UUHC Pasal 6 menyebutkan "Untuk melindungi hak moral sebagaimana dimaksud dalam Pasal 5 ayat (1), Pencipta dapat memiliki:

a. informasi manajemen Hak Cipta; dan/atau

b. informasi elektronik Hak Cipta.

\section{Pasal 7}

(1) Informasi manajemen Hak Cipta sebagaimana dimaksud dalam Pasal 6 huruf a meliputi informasi tentang:

a. metode atau sistem yang dapat mengidentifikasi originalitas substansi Ciptaan dan Penciptanya; dan

b. kode informasi dan kode akses.

(2) Informasi elektronik Hak Cipta sebagaimana dimaksud dalam Pasal 6 huruf b meliputi informasi tentang:

a. suatu Ciptaan, yang muncul dan melekat secara elektronik dalam hubungan dengan kegiatan Pengumuman Ciptaan;

b. nama pencipta, aliasnya atau nama samarannya;

c. Pencipta sebagai Pemegang Hak Cipta;

d. masa dan kondisi penggunaan Ciptaan;

e. nomor; dan

f. kode informasi.

(3) Informasi manajemen Hak Cipta sebagaimana dimaksud pada ayat (1) dan informasi elektronik Hak Cipta sebagaimana dimaksud pada ayat (2) yang dimiliki Pencipta dilarang dihilangkan, diubah, atau dirusak.

Ketentuan Pasal 6 dan Pasal 7 UUHC memberikan wadah bagi pelaksanaan perlindungan dan penegakan hak moral. Dimana hak moral dapat dilindungi melalui upaya kepemilikan informasi manajemen Hak Cipta dan informasi elektronik Hak Cipta. Dalam informasi manajemen kolektif terdapat metode atau sistem yang dapat mengidentifikasi originalistas substansi ciptaan dan penciptanya, serta kode informasi dan kode akses. Sementara informasi elektronik didalamnya terdapat:

a. suatu Ciptaan, yang muncul dan melekat secara elektronik dalam hubungan dengan kegiatan Pengumuman Ciptaan;

b. nama pencipta, aliasnya atau nama samarannya;

c. Pencipta sebagai Pemegang Hak Cipta;

d. masa dan kondisi penggunaan Ciptaan;

e. nomor; dan

f. kode informasi.

Untuk mendapatkan perlindungan hak moral melalui informasi manajemen dan informasi elektronik, pencipta harus mendaftarkan ciptaannya. Hal ini yang masih tidak banyak dilakukan oleh pencipta. Pencipta masih enggan mendaftarkan ciptaannya. Terlebih ciptaan berupa potret. Pencipta baru kemudian merasa haknya dilanggar ketika karya potret dipergunakan tanpa izin untuk kepentingan komersial. Disamping hal tersebut, informasi manajemen Hak Cipta dan informasi elektronik Hak Cipta, pada konvensi internasional digunakan khusus untuk Ciptaan berbentuk DIGITAL yang fungsinya untuk menjaga informasi atas ciptaan digital tersebut, bukan untuk semua jenis ciptaan.

Hak moral memberikan berbagai kontrol kepada pencipta terhadap penggunaan karyakarya ciptanya dengan memberikan hak kepada seorang pencipta untuk mengklaim hasil karyanya sebagai pencipta dari sebuah karya dan mencegah penggunaannya dengan cara yang oleh pencipta layak ditolak atau yang tidak disepakati. ${ }^{11}$

Pengaturan hak moral dalam UUHC sejalan dengan teori John Locke yang mengemukakan bahwa Hak Cipta adalah property. Property identik dengan kepemilikan. Kepemilikan ini harus mendapatkan pengakuan sebagai pencipta. Pengakuan atas usaha dari pencipta khususnya potret dalam mengahasilkanarya terlebih ketika karya itu tersebar luas melalui sosial media. Konsep 
property ini pula melahirkan hak atas keutuhan sebuah karya dan hak untuk menggandakan karya cipta. Semua hak tersebut yang merupakan pengejawantahan dari hak moral harus dilindungi dan merupakan satu kesatuan dengan penciptanya. Kasus pelanggaran hak moral yang dialami oleh Maulina Pia Wulandari dapat diajukan gugatan ke Pengadilan Niaga (Pasal 100 ayat (1) UUHC) atas tindakan penggunaan potret tanpa izin di sosial media. Tidak dimungkinkan adanya tuntuan pidana bagi pelanggaran hak moral sepanjang perbuatan tersebut tidak memenuhi ketentuan pidana UUHC. Hal ini berbeda dengan ketentuan se-be-lumnya yakni Undang-Undang No. 19 Tahun 2002 tentang Hak Cipta. Di un-dang-undang ini diatur ketentuan pi-dana. Pasal 72 ayat (6) mengatur, pe-langgaran hak moral dapat dipidana penjara selama 2 (dua) tahun.

\section{SIMPULAN}

Hak Cipta adalah hak eksklusif yang didalamnya terdapat hak ekonomi dan hak moral. Hak ekonomi adalah hak untuk memanfaatkan ciptaan untuk kepentingan komersial dengan tujuan mendapatkan manfaat ekonomi atas suatu ciptaan. Hak moral adalah bersifat mutlak dan melekat pada diri pencipta. Potret merupakan salah satu ciptaan yang dilindungi. Termasuk potret yang disebarluaskan di sosial media baik untuk kepentingan komersial atau tidak. Dalam potret di sosial media terdapat hak ekonomi dan hak moral. Penggunaan potret di sosial media tanpa izin untuk kepentingan komersial adalah bentuk pelanggaran Hak Cipta. Penggunaan potret di sosial media tanpa mencantumkan pencipta adalah pelanggaran hak moral. Pengaturan dan perlindungan hak ekonomi dan hak moral atas potret di sosial media telah diatur dalam UUHC. Hak ekonomi diatur dalam Pasal 12 sampai Pasal 15. Hak moral diatur dalam Pasal 5 sampai Pasal 7 UUHC. Walaupun pengaturan hak ekonomi dan hak moral telah diatur dalam UUHC, tetapi pelanggaran terhadap Hak Cipta masih tetap terjadi.

\section{DAFTAR PUSTAKA}

Abdul Kadir Muhammad, 2001, Kajian Hukum Ekonomi Hak Kekayaan Intelektual, PT. Citra Aditya Bakti, Bandung

Ayu Mufidah Kartika Sari, Fotonya yang Diedit Netizen Tanpa Izin Diunggah Artis, Dosen UB Malang: Memberi Contoh Buruk, http://jatim.tribunnews.com/2018/ 07/26/fotonya-yang-diedit-netizen-tanpaizin-diunggah-artis-dosen-ub-malangmemberi-contoh-buruk., 26 Juli 2018.

Bernard Nainggolan, 2016, Komentar UndangUndang Hak Cipta, PT. Alumni Bandung, Bandung.

Clara Edwards, The art of posting: social media, copyright and artist attribution, Internet Law Bulletin, May 2016.

Fotonya Dipakai Tanpa Izin, Farah Quinn Gugat Online Shop, http://

hiburan.metrotvnews.com/selebritas/ ZkenGOqK-fotonya-dipakai-tanpa-izinfarah-quinn-gugat-online-shop, 18 Maret 2016.

Ganis Dhenandapinasthi Permana, 2018, Skripsi "Perlindungan Hak Cipta Potret Di Indonesia (Studi Kasus Penggunaan Potret Untuk Video Klip Akad Payung Teduh)", https://dspace.uii.ac.id/ bitstream/handle/123456789/6740/ Skripsi\%20Lengkap.pdf?sequence $=1$ Hendra Tanu Atmadja, Konsep Hak Ekonomi dan Hak Moral Pencipta Menurut Sistem Civil Law dan Common Law, JURNAL HUKUM. NO. 23 VOL 10. MEI 2003:153-168.

Henry Soelistyo, 2011, Hak Cipta Tanpa Hak Moral, PT. RajagrafindoPersada, Jakarta. Kinney \& Lange PA dalam Ni Ketut Supasti Dharmawan, 2011, Hak Kekayaan Intelektual Dan Harmonisasi Hukum Global (Rekonstruksi Pemikiran Terhadap Perlindungan Program Komputer), Badan Penerbit Universitas Diponegoro, Semarang. 
Peter Mahmud Marzuki, 2005, Penelitian Hukum, Prenada Media, Jakarta.

Rachmadi Usman, Rachmadi Usman, 2003, Hukum Hak atas kekayaan Intelektual:Perlindungan dan Dimensi Hukumnya di indonesia, Cetakan ke-1, PT. Alumni, Bandung.

Undang-Undang Republik Indonesia Nomor 28 Tahun 2014 Tentang Hak Cipta

\section{(Footnotes)}

${ }^{1}$ Fotonya Dipakai Tanpa Izin, Farah Quinn Gugat Online Shop, http:// hiburan.metrotvnews.com/selebritas/ ZkenGOqK-fotonya-dipakai-tanpa-izinfarah-quinn-gugat-online-shop, 18 Maret 2016.

${ }^{1}$ Ganis Dhenandapinasthi Permana, 2018, Skripsi "Perlindungan Hak Cipta Potret Di Indonesia (Studi Kasus Penggunaan Potret Untuk Video Klip Akad Payung Teduh) “,https://dspace.uii.ac.id/bitstream/ hand le/123456789/6740/ Skripsi\%20Lengkap.pdf?sequence $=1$, hal.9

${ }^{2}$ Ayu Mufidah Kartika Sari, Fotonya yang Diedit Netizen Tanpa Izin Diunggah Artis, Dosen UB Malang: Memberi Contoh Buruk, http://jatim.tribunnews.com/2018/07/26/fotonyayang-diedit-netizen-tanpa-izin-diunggahartis-dosen-ub-malang-memberi-contohburuk., 26 Juli 2018.

${ }^{1}$ Clara Edwards, The art of posting: social media, copyright and artistattribution, Internet Law Bulletin, May 2016.

2 Henry Soelistyo, 2011, Hak Cipta Tanpa Hak Moral, PT. RajagrafindoPersada, Jakarta, hal.47
${ }^{3}$ Kinney \&Lange PA dalam Ni Ketut Supasti Dharmawan, 2011,

Hak Kekayaan Intelektual Dan Harmonisasi Hukum Global (Rekonstruksi Pemikiran Terhadap Perlindungan Program Komputer), Badan Penerbit Universitas Diponegoro, Semarang, hal.47.

${ }^{4}$ Peter Mahmud Marzuki, 2005, Penelitian Hukum, Prenada Media, Jakarta, hal.142.

${ }^{5}$ Rachmadi Usman, Rachmadi Usman, 2003, Hukum Hak atas kekayaan Intelektual:Perlindungan dan Dimensi Hukumnya di indonesia, Cetakan ke-1, PT. Alumni, Bandung, hal. 112.

${ }^{6}$ Henry Soelistyo, Op.Cit., hal.47

${ }^{7}$ Bernard Nainggolan, 2016, Komentar UndangUndang Hak Cipta, PT. Alumni Bandung, Bandung, hal.74.

8 Ibid.

${ }^{9}$ Kinney \&Lange PA dalam Ni Ketut Supasti Dharmawan,.Loc.Cit.

10 Abdul Kadir Muhammad, 2001, Kajian Hukum Ekonomi Hak Kekayaan Intelektual, PT. Citra Aditya Bakti, Bandung, hlm. 21.

${ }^{11}$ Hendra Tanu Atmadja, Konsep Hak Ekonomi dan Hak Moral Pencipta Menurut Sistem Civil Law dan Common Law, JURNAL HUKUM. NO. 23 VOL 10. MEI 2003:153 -168 , hal.157. 